\title{
PENGARUH MEDIA PERMAINAN KOTAK KATIK TERHADAP HASIL BELAJAR SISWA PADA MATERI REAKSI REDOKS KELAS X SMA NEGERI 1 ALALAK
}

\author{
The Influence of Kotak Katik Games To Student's Learning \\ Outcomes On Redox Material Class X SMA Negeri 1 Alalak
}

\author{
Karina, Novi Rahmawanti, Mohan Taufiq Mashuri \\ Program Studi Pendidikan Kimia Fakultas Keguruan dan Ilmu Pendidikan \\ Universitas Islam Kalimantan Muhammad Arsyad Al Banjari, Banjarmasin \\ *e-mail: karinacapricorn@gmail.com
}

\begin{abstract}
Abstrak. Penelitian dilaksanakan di SMA Negeri 1 Alalak dengan tujuan untuk mengetahui ada atau tidaknya pengaruh media permainan kotak katik terhadap hasil belajar siswa pada materi reaksi redoks. Jenis penelitian yang digunakan adalah kuasi eksperimen dengan rancangan Nonequivalent Control Group Design. Populasi dalam penelitian ini adalah seluruh siswa kelas X MIA yang terdiri dari 3 kelas dengan jumlah 87 siswa. Sampel dalam penelitian ini adalah kelas X MIA 3 sebagai kelas eksperimen dan kelas X MIA 2 sebagai kelas kontrol. Teknik pengumpul data yang digunakan adalah dokumentasi dan tes. Dokumentasi menyangkut foto-foto kegiatan saat pembelajaran berlangsung, sedangkan tes berupa soal pilihan ganda berjumlah 20 butir soal. Data post-test yang diperoleh diuji menggunakan Independent sample t-test. Hasil pengujian tersebut menunjukkan bahwa terdapat pengaruh media permainan kotak katik terhadap hasil belajar siswa pada materi reaksi redoks.
\end{abstract}

Kata Kunci: Hasil Belajar, Permainan Kotak Katik, Reaksi Redoks

\begin{abstract}
The study was conducted at SMAN 1 Alalak with the aim of knowing whether or not the influence of the kotak katik games on student learning outcomes in the redox reaction. The type of research used was quasi-experimental with Nonequivalent Control Group Design. The population in this study were all students of class X MIA consisting of 3 classes with a total of 87 students. The sample in this study was class X MIA 3 as the experimental group and class $X$ MIA 2 as the control group. The data collection technique used is documentation and tests. Documentation involves photos of activities when learning takes place, while tests in the form of multiple choice questions amount to 20 items. Post-test data obtained were tested using the Independent sample t-test. The results of these tests indicate that there are influences of kotak katik games on student learning outcomes in redox reaction.
\end{abstract}

Keywords: Kotak Katik Games, Learning Outcomes, Redox Reactions

\section{PENDAHULUAN}

Ilmu kimia merupakan salah satu cabang dari sains yang secara khusus mempelajari tentang eksistensi materi ditinjau dari segi struktur, sifat-sifat, perubahan, dan perubahan energi yang menyertai perubahan tersebut (Jespersen, Brady, dan Hyslop, 2012). Sebagian konsep yang terdapat pada ilmu kimia dipelajari oleh siswa SMA/MA sederajat. Namun, minat siswa SMA dalam mempelajari materi kimia semakin 
berkurang, salah satu penyebabnya adalah cara guru dalam mengajarkan ilmu kimia (Subagia, 2014).

Secara umum, pembelajaran kimia di SMA masih didominasi guru melalui metode ceramah dan pemberian soal latihan. Metode demikian menganggap siswa yang belajar sebagai individu pasif. Padahal, belajar lebih banyak ditentukan karena adanya karsa siswa. Oleh karena itu keaktifan siswa dalam belajar menjadi unsur yang amat penting dalam menentukan kesuksesan belajar (Budiningsih, 2015).

Keaktifan siswa dan lingkungan belajar yang asyik dapat diciptakan oleh guru sebagai fasilitator dan pembimbing selama proses pembelajaran. Pengemasan materi pelajaran dengan cara tertentu mampu mengaktifkan siswa dan menciptakan suasana belajar yang menyenangkan. Salah satu cara yang dapat digunakan guru adalah dengan menggunakan media pembelajaran. Penggunaan media pembelajaran memang sangat penting, karena melalui media, pembelajaran dapat dilakukan secara maksimal (Santyasa, 2007). Menurut Sudjana \& Rivai (2010) media pembelajaran dapat berupa alat peraga, demonstrasi, permainan dan lain-lain.

Permainan (games) adalah kontes antara para pemain yang berinteraksi antara satu sama lain denga mengikuti aturan-aturan tertentu untuk mencapai tujuan-tujuan tertentu pula (Sadiman dkk., 2012). Permainan tidak hanya disukai oleh anak usia 1-14 tahun, tetapi juga disukai oleh anak remaja berusia 15-18 tahun. Penggunaan permainan dalam pembelajaran bertujuan untuk menciptakan suasana belajar yang rekreatif (Priatmoko dkk., 2012), memberikan pengalaman yang menarik bagi siswa dalam memahami suatu konsep, menguatkan konsep yang telah difahami, atau memecahkan masalah, meningkatkan motivasi instrinsik siswa, memberikan kesempatan kepada siswa untuk berlatih mengambil keputusan, mengembangkan pengendalian emodi apabila siswa menang atau kalah (Hamdani, 2011).

Salah satu bentuk media permainan adalah kotak katik. Menurut Rusly (2017), permainan kotak katik merupakan jenis permainan yang melibatkan strategi serta keaktifan dari seluruh peserta. Dalam permainan ini peserta diharuskan berpikir cepat, tanggap dan harus tepat dalam mengambil keputusan serta menjawab karena dibatasi oleh waktu. Permainan kotak katik dapat menciptakan suasana yang menyenangkan dan menantang dalam kegiatan pembelajaran. Selain itu, permainan kotak katik juga dapat membantu siswa memahami suatu materi pelajaran, karena di dalam permainan tersebut terdapat pertanyaan-pertanyaan untuk melatih pemahaman siswa.

Salah satu materi kimia yang dianggap sulit oleh siswa adalah reaksi redoks. Terdapat beberapa konsep yang harus dipelajari siswa pada materi tersebut, yaitu: (1) perkembangan konsep reaksi reduksi dan oksidasi, (2) konsep bilangan oksidasi, (3) reduktor dan oksidator, (4) reaksi autoredoks, (5) penerapan reaksi redoks dalam kehidupan sehari-hari (Yulianingtyas dkk., 2017). Dari konsep-konsep tersebut, dapat diketahui bahwa terdapat kaitan antar konsep dan perhitungan matematika sederhana. Keterkaitan antar konsep ini dapat ditunjukkan dengan adanya hubungan konsep bilangan oksidasi dengan konsep-konsep sebelumnya, seperti sistem periodik unsur, konfigurasi elektron, dan ikatan kimia. Keterkaitan konsep-konsep ini diduga menjadi penyebab kesulitan siswa dalam mempelajari materi reaksi redoks (Yulianingtyas dkk., 2017). Materi reaksi redoks yang dianggap sulit oleh siswa akan dikemas ke dalam permainan kotak katik, dengan harapan hasil belajar siswa dapat dicapai secara maksimal. 
Efektivitas penggunaan media kotak katik dalam pembelajaran IPA telah dibuktikan oleh Murwaningsih dkk (2016). Hasil penelitian tersebut menyebutkan bahwa permainan kotak katik IPA sebagai media pembelajaran dinyatakan sangat efektif dengan persentase ketuntasan klasikal hasil belajar siswa sebesar $87,5 \%$ dan persentase peningkatan hasil belajar siswa sebesar $100 \%$. Peneliti lain yang mendukung hasil penelitian tersebut adalah Kurniasih \& Sukanti (2016). Hasil penelitian tersebut menjelaskan bahwa terjadi peningkatan skor di setiap indikator aktivitas belajar akuntansi dari siklus I ke siklus II serta peningkatan skor rata-rata aktivitas belajar akuntansi dari siklus I ke siklus II sebesar 23,52\%.

Berdasarkan uraian yang telah dijelaskan terkait permasalahan yang dihadapi siswa dalam mempelajari materi kimia, khususnya materi reaksi redoks dan cara pembelajaran yang dianggap dapat meningkatkan hasil belajar siswa, mendorong peneliti untuk melakukan penelitian mengenai pengaruh permainan kotak katik pada materi reaksi redoks terhadap hasil belajar siswa. Penelitian ini bertujuan untuk mengetahui pengaruh permainan kotak katik terhadap hasil belajar siswa pada materi reaksi redoks.

\section{METODE PENELITIAN}

Jenis penelitian ini adalah kuasi eksperimen dengan desain nonequivalent control group design. Desain penelitian Nonequevalent Control Group Design dapat dilihat pada Tabel 1 berikut.

Tabel 1. Desain Nonequivalent Control Group Design

\begin{tabular}{cccc}
\hline Kelas & Pre-test & Perlakuan & Post-test \\
\hline Eksperimen & $\mathrm{O}_{1}$ & $\mathrm{X}$ & $\mathrm{O}_{2}$ \\
Kontrol & $\mathrm{O}_{3}$ & - & $\mathrm{O}_{4}$ \\
\hline
\end{tabular}

Sumber : Sugiyono (2015:116)

Keterangan :

$\mathrm{O}_{1} \quad=$ Pre-test kelas eksperimen

$\mathrm{O}_{2} \quad=$ Post-test kelas eksperimen

$\mathrm{O}_{3} \quad=$ Pre-test kelas kontrol

$\mathrm{O}_{4} \quad=$ Post-test kelas kontrol

$\mathrm{X} \quad=$ Perlakuan pembelajaran menggunakan media permainan kotak katik pada kelas eksperimen

Penelitian dilakukan di SMA Negeri 1 Alalak pada tahun ajaran 2018 /2019. Populasi penelitian adalah seluruh siswa kelas X MIA SMA Negeri 1 Alalak yang terdiri dari 3 kelas dengan jumlah 87 siswa. Sampel penelitian adalah siswa kelas X MIA 2 dan kelas X MIA 3. Siswa kelas X MIA 2 sebagai kelompok kontrol, dan siswa kelas X MIA 3 sebagai kelompok eksperimen.

Data penelitian dikumpulkan menggunakan teknik dokumentasi dan tes. Teknik dokumentasi yang dimaksud dalam penelitian ini adalah foto-foto saat kegiatan pembelajaran berlangsung, sedangkan teknik tes yang dimaksud adalah soal pilihan ganda dengan lima alternatif jawaban guna mengukur hasil belajar siswa sebelum dan sesudah treatment dilakukan. Data-data yang diperoleh dari hasil belajar siswa dianalisis 
menggunakan independent sample t test. Rumus yang digunakan pada uji tersebut adalah Polled Varians (Sugiyono, 2015) dengan formula berikut.

$$
t=\frac{x_{1}-x_{2}}{\sqrt{\frac{\left(n_{1}-1\right) s_{1}^{2}+\left(n_{2}-1\right) s_{2}^{2}}{n_{1}+n_{2}-2}\left(\frac{1}{n_{1}}+\frac{1}{n_{2}}\right)}}
$$

Keterangan :

$x_{1}=$ Rata-rata sampel 1

$x_{2}=$ Rata-rata sampel 2

$n_{1}=$ Jumlah sampel 1

$n_{2}=$ Jumlah sampel 2

$S_{1}^{2}=$ Varians sampel 1

$s_{2}^{2}=$ Varians sampel 2

\section{HASIL DAN PEMBAHASAN}

Analisis Data Pre-test

Analisis terhadap data pre-test bertujuan untuk mengetahui kemampuan awal siswa sebelum mempelajari materi reaksi redoks. Ringkasan data pre-test dapat dilihat pada Gambar 1 berikut.

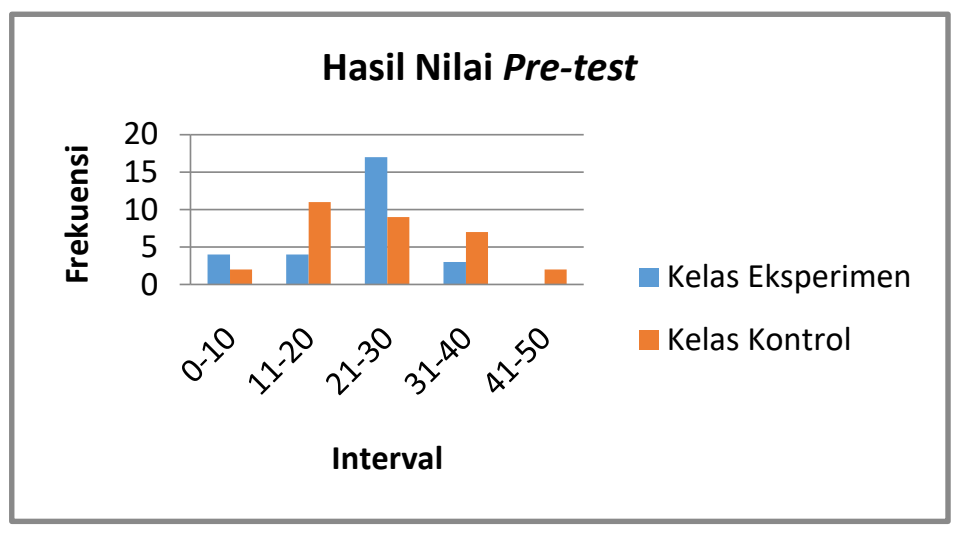

Gambar 1. Diagram Ringkasan Hasil Nilai Pre-test

Dari Gambar 1 diketahui bahwa nilai pre-test siswa di kelompok eksperimen dan kontrol masih berada di bawah kriteria ketuntasan maksimal (KKM) yang telah ditentukan, yaitu 75. Hal ini dikarenakan para siswa belum belajar materi reaksi redoks, sehingga siswa tidak bisa menyelesaikan atau memecahkan tes yang diberikan. Ringkasan nilai pre-test siswa kelompok kontrol dan eksperimen dapat dilihat pada Tabel 1. 
Tabel 1 Nilai Pre-test Siswa

\begin{tabular}{ccc}
\hline Nilai & Kelas Eksperimen & Kelas Kontrol \\
\hline Terendah & 0 & 0 \\
\hline Tertinggi & 40 & 50 \\
\hline Rata - rata & 23,4 & 26,0 \\
\hline
\end{tabular}

Dari Tabel 1 diketahui bahwa nilai rata-rata pre-test siswa kelompok eksperimen lebih rendah dari pada kelompok kontrol, dengan selisih nilai sebesar 2,6. Dengan demikian, kemampuan awal siswa sebelum dilakukan pembelajaran dapat dianggap tidak berbeda.

\section{Analisis Data Post-test}

Analisis terhadap data post-test ini bertujuan untuk mengetahui kemampuan akhir siswa setelah mempelajari materi reaksi redoks. Ringkasan nilai post-test siswa dapat dilihat pada Gambar 2.

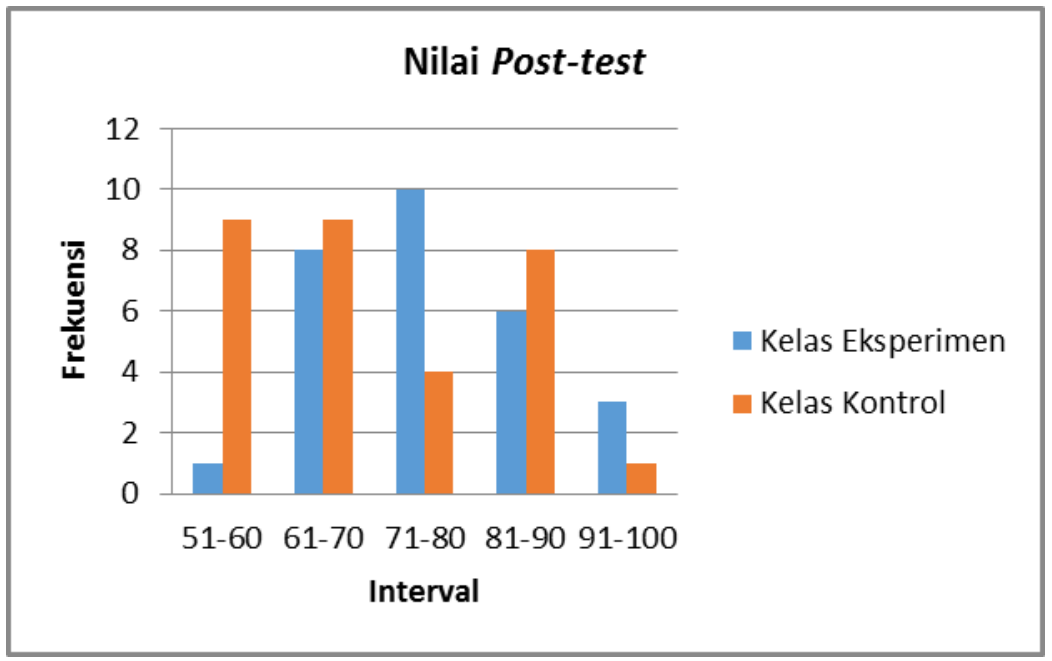

Gambar 2. Ringkasan Nilai Post-test

Dari Gambar 2 diketahui bahwa nilai posttest siswa baik kelompok kontrol maupun eksperimen sama-sama mengalami peningkatan jika dibandingkan dengan nilai pre-test siswa pada Gambar 1. Meskipun demikian, masih terdapat beberapa siswa baik di kelompok kontrol maupun eksperimen yang belum mencapai KKM yang ditentukan. Perhitungan rata-rata nilai post-test siswa di kelompok kontrol dan eksperimen secara berturut-turut adalah 72,1 dan 78,4. Hal ini menunjukkan bahwa nilai post-test siswa di kelompok eksperimen lebih tinggi daripada kelompok kontrol dengan selisih sebesar 6,3.

Data post-test yang diperoleh, diuji normalitasnya untuk mengetahui penyebaran data menggunakan uji Liliefors. Hasil uji normalitas tersebut dapat dilihat pada Tabel 2. 
Tabel 2 Hasil Uji Normalitas Post-test

\begin{tabular}{ccccc}
\hline Kelas & $\mathbf{N}$ & $\boldsymbol{\alpha}$ & $\mathbf{L}$ & Ltabel \\
\hline Kontrol & 31 & 0,05 & 0,133 & 0,886 \\
Eksperimen & 28 & 0,05 & 0,049 & 0,161 \\
\hline
\end{tabular}

Berdasarkan Tabel 2 menunjukkan bahwa nilai $\mathrm{L}_{0}$ lebih kecil dari $\mathrm{L}_{\text {tabel}}$, sehingga dapat disimpulkan bahwa data post-test siswa di kelompok kontrol dan eksperimen terdistribusi normal. Selain dilakukan uji normalitas, pada data post-test juga dilakukan uji homogenitas. Hasil uji homogenitas dapat dilihat pada Tabel 3.

Tabel 3 Hasil Uji Homogenitas Post-test

\begin{tabular}{ccccc}
\hline Kelas & $\mathbf{N}$ & Sd & Fitung $_{\text {hibel }}$ & F $_{\text {tabel }}$ \\
\hline Kontrol & 3 & 10,3 & & \\
& 1 & & 1,09 & \\
Eksperimen & 2 & 11,2 & & \\
& 8 & & & \\
\hline
\end{tabular}

Dari Tabel 3 diketahui bahwa $F_{\text {hitung }}$ lebih kecil daripada $F_{\text {tabel, }}$, sehingga dapat disimpulkan bahwa data post-test siswa kelompok kontrol dan eksperimen bersifat homogen. Hasil uji normalitas dan homogenitas pada Tabel 2 dan 3 menunjukkan bahwa syarat parametrik terpenuhi, sehingga uji hipotesis yang digunakan adalah independent sample t-test. Hasil uji hipotesis tersebut dapat dilihat pada Tabel 4 berikut.

\section{Tabel 4 Hasil Independent Sample t-test}

\begin{tabular}{ccccc} 
Kelas & $\mathbf{N}$ & $\boldsymbol{\alpha}$ & $\mathbf{t}_{\text {hitung }}$ & $\mathbf{t}_{\text {tabel }}$ \\
Kontrol & 31 & 0,05 & & \\
Eksperime & 28 & 0,05 & 2,247 & 2,000 \\
$\mathrm{n}$ & & & & \\
\hline
\end{tabular}

Dari Tabel 4 diketahui bahwa $t_{\text {hitung }}$ lebih besar daripada $t_{\text {tabel }}$, sehingga dapat disimpulkan bahwa terdapat perbedaan hasil post-test siswa pada kelompok kontrol dan eksperimen. Rata-rata nilai post-test siswa kelompok eksperimen lebih tinggi daripada siswa kelompok kontrol dengan selisih nilai sebesar 6,3. Dengan demikian, hasil belajar siswa kelompok eksperimen yang dibelajarkan dengan menggunakan media permainan kotak katik lebih baik daripada kelompok kontrol yang hanya dibelajarkan dengan pembelajaran langsung.

Selama pembelajaran berlangsung, menurut pengamatan peneliti permainan kotak katik mampu meningkatkan aktivitas siswa dalam hal berdiskusi, mencari informasi dan 
jawaban, berpendapat, dan berani mengambil keputusan. Selain itu, terdapat pula poinpoin penting mengapa media permainan dapat meningkatkan hasil belajar siswa, yaitu: (1) bermain merupakan media sekaligus cara terbaik untuk belajar, karena guru berhasil menciptakan lingkungan belajar yang menarik dan menyenangkan, sehingga siswa mudah memahami bahan pelajaran yang disajikan (Hamdani, 2011), (2) memberikan pengalaman yang menarik bagi siswa dalam memahami suatu konsep, menguatkan konsep yang telah difahami (Murwaningsih dkk, 2016), (3) meningkatkan motivasi intrinsik belajar siswa (Hamdani, 2011).

Hasil penelitian ini sejalan dengan hasil penelitian yang telah dilakukan oleh Murwaningsih (2016), Hidayah dkk (2017). Hasil penelitian Murwaningsih (2016) menyebutkan bahwa permainan kotak katik IPA sebagai media pembelajaran dinyatakan sangat efektif dengan persentase ketuntasan klasikal hasil belajar siswa sebesar 87,5\% dan persentase peningkatan hasil belajar siswa sebesar 100\%. Hasil penelitian Hidayah dkk (2017) menjelaskan bahwa media permainan "kimia kotak katik" layak digunakan dalam pembelajaran kimia, dan mampu meningkatkan hasil belajar siswa, meskipun ketuntasan klasikal tidak tecapai.

\section{PENUTUP}

Berdasarkan hasil dan pembahasan, maka dapat disimpulkan bahwa terdapat pengaruh media permainan kotak katik terhadap hasil belajar siswa pada materi reaksi redoks kelas X SMA Negeri 1 Alalak. Berdasarkan hasil dan kesimpulan dalam penelitian ini, peneliti menyampaikan beberapa saran antara lain :

1. Guru dapat menggunakan media permainan kotak katik sebagai media pembelajaran khususnya pada mata pelajaran kimia materi reaksi redoks.

2. Peneliti selanjutnya dapat meneliti media permainan kotak katik terhadap prestasi siswa, minat siswa dan motivasi siswa.

\section{DAFTAR RUJUKAN}

Budiningsih, C. A. (2015). Belajar dan Pembelajaran. Jakarta: Rineka Cipta.

Finlam, K.. (2016). Implementasi Model Pembelajaran Kooperatif Tipe Student Teams Achievement Division (STAD) Brbantu Permainan Kotak Katik Untuk Meningkatkan Aktivitas Belajar Akuntansi Siswa Kelas X Akuntansi 2 SMK Negeri 1 Pengasih Tahun Ajaran 2015/2016. Jurnal Kajian Pendidikan Akuntansi Indonesia, 5: 1-12.

Hamdani. (2011). Strategi Belajar Mengajar. Bandung: CV. Pustaka Setia.

Hidayah, R., Suprianto. \& Rahmawati, A. 2017. Permainan "Kimia Kotak Katik" Sebagai Media Pembelajaran Pada Materi Sistem Periodik Unsur. Jurnal Tadris Kimiya 2, 1 (Juni 2017) : 91-96.

Murwaningsih, E, A., Susantini, E., \& Widodo, W. (2016). Pengembangan Kotak Katik IPA Pada Materi Sistem Ekskresi Sebagai Media Pembelajaran Siswa Di SMA. Jurnal Pendidikan Sains, 4(3):1-8.

Priatmoko,S., Saptorini. \& Diniy, H.H. (2012). Penggunaan Media Sirkuit Cerdik Berbasis Chemo-Edutainment Dalam Pembelajaran Larutan Asam Basa. Jurnal Pendidikan IPA Indonesia, 1(1): 37-42. 
Dalton : Jurnal Pendidikan Kimia dan Ilmu Kimia, Volume 1 Nomor 2, November 2018

Sadiman, A. S., Rahardjo, R., Haryono, A. \& Harjito. (2012). Media Pendidikan: Pengertian, Pengembangan, dan Pemanfaatannya. Jakarta: PT Raja Grafindo Persada.

Santyasa,I. W. (2007). Landasan Konseptual Media Pembelajaran. Makalah disajikan dalam Workshop Banjar Angklan Klungkung, Universitas Pendidikan Ganesha, 10 Januari 2007.

Subagia, I. W. (2014). Paradigma Baru Pembelajaran Kimia SMA. Makalah disajikan pada Seminar Nasional FMIPA UNDIKSHA IV Tahun 2014, Universitas Pendidikan Ganesha, 11 Oktober 2014.

Sudjana, N \& Rivai. (2010). Media Pengajaran. Bandung: Sinar Baru Algensindo.

Sugiyono. (2015). Metode Penelitian Kuantitatif Kualitatif dan R\& D. Bandung: Alfabeta.

Yulianingtyas, E., Budiasih, E. \& Marfuah, S. (2017). Pengaruh Penggunaan Jurnal Belajar dalam Model Pembelajaran Learning Cycle 6E terhadap Kesadaran Metakognitif Siswa SMAN 8 Malang pada Materi Redoks. Jurnal Pendidikan: Teori, Penelitian, dan Pengembangan, 2(5):724-730. 